\title{
Fiscal Devolution and Human Capital Formation in Nigeria: Emphasis on Independent Generated Funds of the Three Tiers of Government
}

\author{
Cordelia Onyinyechi Omodero ${ }^{1}$ \\ ${ }^{1}$ Department of Accounting, College of Management Sciences,, Michael Okpara University of Agriculture, \\ Umudike, Umuahia, Abia State, Nigeria \\ Correspondence: Cordelia Onyinyechi Omodero, Department of Accounting, College of Management Sciences, \\ Michael Okpara University of Agriculture, Umudike, Umuahia, Abia State, Nigeria.
}

Received: February 9, 2019

Accepted: February 26, 2019

Online Published: March 13, 2019

doi:10.5539/ibr.v12n4p21

URL: https://doi.org/10.5539/ibr.v12n4p21

\begin{abstract}
The benefits of human capital in a nation are enormous and all encompassing. This study investigates the impact of independent generated revenue of the three tiers of government in Nigeria on human capital formation from 2003 to 2017. The purpose is to determine the effect of internally generated revenue of each level of government on human beings in the country. Revenue powers of three tiers of government in Nigeria are the product of fiscal decentralization being practiced in the country. Thus, Ordinary Least Square technique has been employed to perform the multi-regression analysis using Statistical Package for Social Sciences (SPSS) version 20. The findings indicate that federal and local governments' independent generated funds do not have significant positive impact on human capital development while the state government independent generated revenue exerts significant positive influence on human development index used as proxy for human capital formation in Nigeria. Therefore, the study recommends among others that the three levels of government in the country should strive harder to boost independent revenues for more adequate investment in human capital of the nation.
\end{abstract}

Keywords: fiscal decentralization, human capital formation, internally generated revenue, three tiers of government, Nigeria

\section{JEL Classification: I31, H71, H77}

\section{Introduction}

Fiscal decentralization has given credence to devolution of revenue raising powers as well as spending responsibilities to sub-national governments (Sarkar, 2000). Scholars such as (Bahl \& Linn, 1992; Bird \& Wallic, 1993) advocated fiscal decentralization because they held that it enhances public service delivery and improves efficiency in the public sector. It enables the government to provide public services speedily and in a more efficient and desirable manner (Soejoto, Subroto \& Suyanto, 2015). Fiscal decentralization is the delegation of economic or monetary functions to the lower level governments from the government at the top (Rauf, Khan, Ali, Qureshi, Ahmad \& Anwar, 2017). It is believed that economic devolution encourages accountability and transparency at all levels of government and public administration (Gogoi, 2017) and it is trusted to be a solution to all kinds of economic and political challenges facing developing countries despite its inherent glitches (Jumadi, Ghozali \& Khusaini, 2013).

Although, fiscal decentralization is generally understood to be a means by which all levels of government in a country deliver better services to citizens, yet Yasemin (2016) argues that fiscal decentralization and other forms of devolution of power are capable of preventing the government at the center from ensuring that revenues are evenly distributed among different tiers of government in a country. Yasemin (2016) made this discovery during his study in Spain where he deduced likely unwillingness on the part of the central government to implement policies that tend to minimize inequalities caused by division of revenue powers.

In Nigeria fiscal decentralization is practiced through the division of taxing powers and spending obligations among the three tiers of government. The revenue powers of the three levels of government in Nigeria are stipulated in the second schedule part II of the 1999 Constitution of the Federal Republic of Nigeria (FRN). The purpose of the division of these taxing powers among the three tiers of government is to exploit resources for 
proper public service delivery in the country. Human capital formation is the major aspect of public service delivery the independent revenues generated by the three tiers of government are meant to address in all earnest. This is because the quality of human capital a nation has determines its rapid growth socially and economically. The economic strength of Nigeria relies on the ability of the country to raise health human capital with the knowledge and expertise to ensure that the nation's economy meets the global standard of poverty management and reduction.

If government's budget on education, health and infrastructures that aid human capital development in Nigeria is critically evaluated, it will be fair to assert that the government has made some reasonable efforts. Some of the commendable efforts the government has made to develop human capital in the country is the provision of Tertiary Education Trust Fund (TETFUND) for infrastructural development in the government owned Universities, Polytechnics and Colleges of Education. Research grants are also given to Academic workers to carry out researches, publish journals and books. However, the crucial needs in the education and health sectors in the country deserve more government interventions and attention. The role of independent generated funds of the three tiers of government in affecting human capacity building in Nigeria is what this study is targeted to establish.

\subsection{Objective of the Study}

The general objective of this study is to determine the impact of independent generated revenue on human capital formation in Nigeria.

The specific objectives are:

1. To examine the impact of federal government independent revenue on human capital development using human development index (HDI) as proxy.

2. To assess the effect of state government independent revenue on HDI.

3. To evaluate the influence of local government independent revenue on HDI.

\subsection{Hypotheses}

The following study hypotheses have been formulated to achieve the above specific objectives:

Ho1: Federal government independent generated revenue does not have significant influence on

Human capital development (HDI) in Nigeria.

Ho2: State governments independent generated revenue does not significantly affect HDI.

Ho3: Local government independent generated revenue does not significantly influence HDI.

\section{Literature Review}

\subsection{Conceptual Framework}

The Figure 1 below depicts the conceptual framework of the study. It shows the fiscal decentralization practiced in Nigeria with emphasis on revenues generated by the three tiers of government and the impact on human capital development represented by human development index.

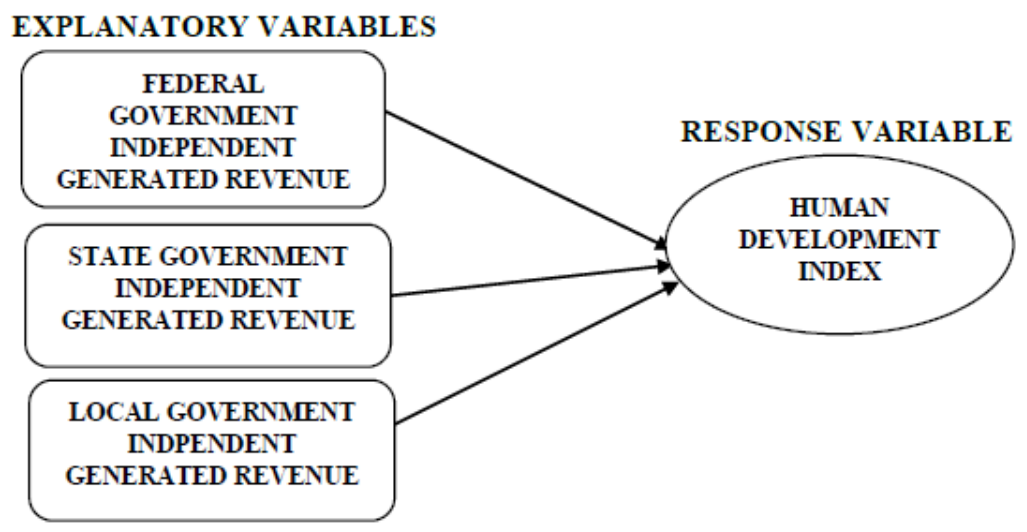

Source: Author's desk research, 2019.

Figure 1. Independent Generated Revenue and Human Development Index 


\subsubsection{Independent Generated Revenue (IGR)}

Abiola and Ehigiamusoe (2014) defined IGR as the revenue that the Federal government, State governments and Local government Councils generate within their areas of jurisdiction. Independent generated revenue in Nigeria are those non-oil sources of government revenue produced by the federal, states and local government councils which aid the enlargement and expansion of the entire non-oil revenue structure of the nation (Oti \& Odey, 2017). Therefore, independent generated revenue is defined as the funds generated by the effort of different levels of government within their territory and confines allowed by the law and constitution of the country. Some revenue sources are not independently managed but are wholly owned by the federation; therefore, the extent to which the law of a nation allows each level of government to control resources will be the level of its operation.

\subsubsection{Fiscal Decentralization and Human Capital Development}

Fiscal decentralization implies freeing certain governing capabilities to the elected bodies at local level within the confines of the law including the opportunity to establish taxable level for collection of some specific local taxes, as well as the right of use of the revenues according to the needs of the respective communities (Dragusha \& Osmani, 2012). In addition, Ocheni and Agba (2018) posit that fiscal decentralization is the transfer of monetary authority and responsibilities from the Central government to other levels of government for the purpose of improving public service delivery, encouraging economic growth, prompting human capital development and increasing actual infrastructural development. Harbison (1973) describes human capital formation as the increasing and acquiring of a good number of healthy individuals who have the required expertise, capability, training, as well as understanding which are important for economic growth and expansion. Therefore, human development index (HDI) is the tool used by the United Nations Development Program (UNDP) to measure economic development of a nation using parameters such as: life expectancy, education and national income which is the standard of living (UNDP, 2018). Lin (2018) submits that the major issue with HDI is its failure to take into cognizance of the disparity among persons as well as the collective benefits and drawbacks in all areas of human endeavor. Ocheni \& Agba (2018) maintain that fiscal decentralization that will produce the desired sustainable economic development of a nation in the area of public service delivery and efficiency in resource allocation should have human capacity building as a focus.

\subsection{Theoretical Framework}

The theoretical backing for this study is the Fiscal Decentralization Theory pioneered by Oates (1972) and supported by so many other scholars among them are (Bahl \& Linn, 1992; Bird \& Wallich, 1993). Fiscal decentralization theory states that revenue powers and spending responsibilities should be divided between the central government and the lower governments for the purpose of proper delivery of public goods and services. Proponents of this theory amplified it by submitting that local governments are closer to the people and understand their needs than the central government and so substantial revenue powers should be given to the lower governments to carry out expenditure responsibilities in their domain. Economic regionalization is also understood to be a transformation platform to improve public sector productivity, attract healthy competition among states and local governments in the area of public service delivery that boost human capital development for economic growth (Bahl \& Linn, 1992; Bird \& Wallich 1993). It is a system where government structure allows responsibilities, functions and resources to be shared between the higher and the lower government levels. The major aim of decentralizing revenue generation and expenditure responsibilities is to improve the efficiency of the public sector, eliminate the budget shortfalls, and develop human capital which promotes economic growth (Bird, 1993; Bird \& Wallich, 1993; Bahl \& Linn, 1992; Gramlich, 1993 and Oates, 1993). Despite the potential challenges of fiscal decentralization it helps to increase economic efficiency because local governments are better positioned than the central government to deliver public services that match local preferences and needs of the human beings in the country (Oates, 1972).

\subsection{Empirical Review}

Rashid and Saqid (2010) used econometric time series technique to analyze the relationship between human development and fiscal decentralization in Pakistan. The aim of the study was to establish the channels through which decentralization stimulates the pace of economic growth and influence the provision of health and education facilities across the Pakistan Provinces. The study established a long-run relationship between fiscal decentralization and human development. The findings also revealed that fiscal decentralization promoted human development and encouraged peaceful co-existence among the provinces in Pakistan.

Jumadi et al. (2013) carried out a study using panel data of 29 districts and 9 cities in East Java Province of Indonesia from 2007 to 2010 . The aim of the study was to determine the effect of fiscal decentralization on various economic indices including human development. The findings revealed among others, that fiscal 
decentralization impacted positively and significantly on human development and physical development. On the other hand, the study also indicated that human development and physical development had positive and significant influence on local economic growth in Indonesian districts and cities.

Soejoto et al. (2015) made use of theoretical and empirical literatures in the analysis of fiscal decentralization policy in promoting Indonesia human development. The study found that decentralized revenue had positive impact on human development due to the improvement on public service delivery and economic growth which in general led to reduction in poverty level in the country.

Udoh, Afangideh and Udeaja (2015) applied Autoregressive Distributed Lag (ARDL) approach to assess the impact of fiscal decentralization on human resource development in Nigeria from 1980-2012. The findings revealed that expenditure decentralization exerted negative effect on human resource development.

Iftikhar (2016) did a cross-country study using 62 countries to investigate the effects of fiscal decentralization on the education sector. Though the study revealed that teaching quality was not maintained despite the tendency of sub-national governments to increase funds allocated to education, all the same, there was evidence of positive effect on local social needs.

Rauf et al. (2017) employed annual time series data from 1972-2009 to examine the effect of fiscal decentralization on education sector in Pakistan. Using education as proxy for public service delivery, the study found support for fiscal decentralization theory that devolution of expenditure responsibilities among all levels of government advances public service delivery because school enrollment in Pakistan generally improved as economic regionalization is being implemented.

Gogoi (2017) made use of human development index of 2011 and devolution index of 2009 to assess the impact of fiscal decentralization on human development in a comparative study of Assam with other states in India. The study found a moderately positive relationship of 38\% which indicated that the human development in Indian states could not promptly respond to the fiscal decentralization outcomes evidenced by developmental economic and social changes in India.

Shelleh (2017) employed a panel data of 31 developing countries from 1984-2012 to examine the impact of fiscal decentralization on three indicators of institutional quality which he identified as: democratic accountability, corruption, law and order. The study revealed that, expenditure decentralization promoted institutional quality while the revenue decentralization weakened the system.

\subsection{Research Gap}

Studies on fiscal decentralization are numerous, though the selected studies reviewed above were carried out in different countries and on different areas of power devolution, but this study tries to carve a niche by filling a gap in the area of impact analysis of independent generated revenue of the three levels of government on human development in Nigeria. The revenue power of the three tiers of government in Nigeria is a product of fiscal decentralization practiced in the country. However, the effect of these taxing powers on human beings that determine economic growth in the country has been scarcely verified, hence the study is motivated to provide an empirical evidence in this area.

\section{Methodology}

This study employs an ex-post facto research design which involves using secondary form of data that are not under the control of the researcher. The dependent variable is the Human Development Index (HDI) used as proxy for human capital formation in Nigeria. The data on HDI were collected from the United Nations Development Programme (UNDP) reports. The independent variables include: federal government independent generated revenue (FIGR), State governments independent generated revenue (SIGR) and local governments independent generated revenue (LIGR).

The data on FIGR were extracted from Central Bank of Nigeria (CBN) annual reports as captured under the fiscal policy while the data for SIGR and LIGR emanated from CBN Statistical Bulletin, 2017 edition. In order to achieve uniformity of the data sets, all the data were expressed in a logarithm formula except the HDI which were already stated in a logged form. The data were analyzed with Statistical Package for Social Sciences (SPSS) version 20. All the hypotheses for this study are null hypotheses and the rejection criterion is that if the p-value is less than 5\%, Ho is rejected and if the p-value if greater than 5\% level of significance Ho is accepted.

The multiple regression model adopted is:

HDI $=\quad \beta 0+\beta_{1}($ LOGFIGR $)+\beta_{2}($ LOGSIGR $)+\beta_{3}($ LOGLIGR $)+\varepsilon$ 
Where,

HDI $=$ Human Development Index

FIGR $=$ Federal Government Independent Generated Revenue

SIGR $=$ State Government Independent Generated Revenue

LIGR $=$ Local Government Independent Generated Revenue

$\beta 0=$ Constant

$\beta_{1}-\beta_{3}=$ Regression Coefficients

$\varepsilon=$ error term

A Priori economic expectation:

$\beta_{1}, \beta_{2}, \beta_{3}>0$

The a priori economic expectation is that FIGR, SIGR and LIGR should be greater than zero signifying positive impact on HDI.

\section{Data Analysis and Interpretations}

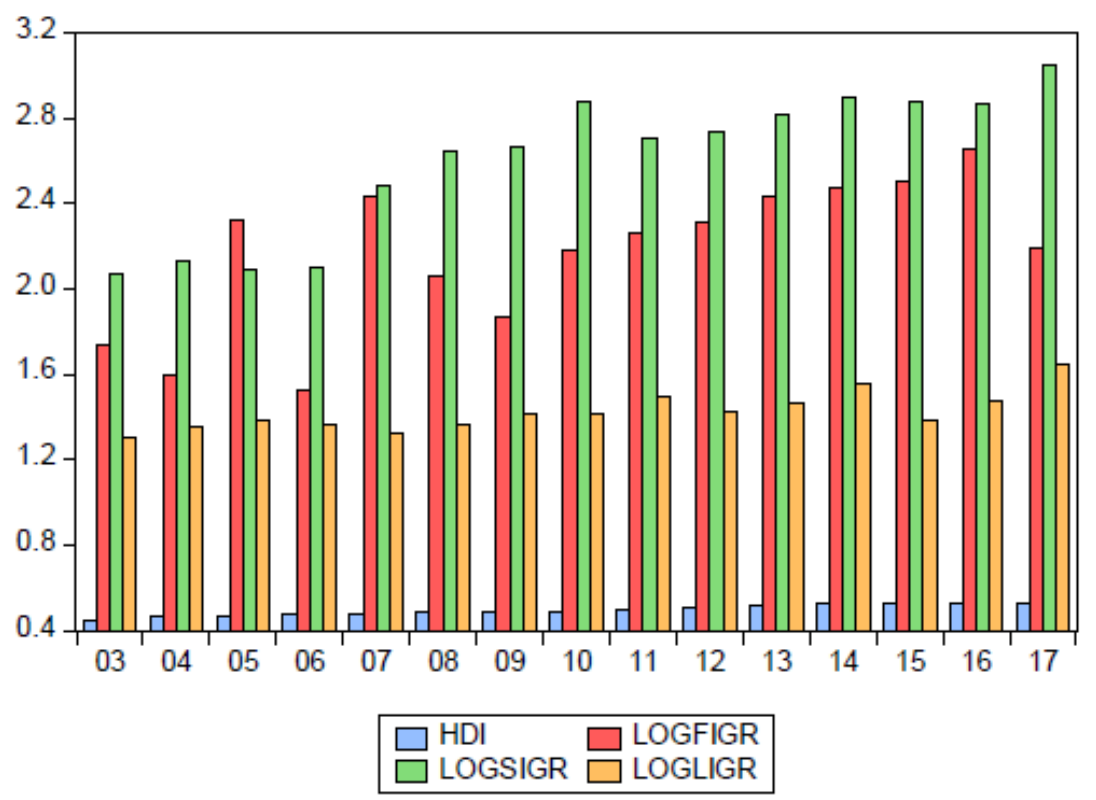

Figure 2. Trend of IGR and HDI in Nigeria from 2003-2017

\section{SOURCE OF DATE: CBN STATISTICAL BULLETIN, 2017 EDITION AND UNDP, 2018.}

Figure 1 above shows the trend of independent revenue generated by the three tiers of government in Nigeria and the human development index from 2003-2017. The figure 1above shows that the SIGR progressed more than the other explanatory variables, followed by the FIGR and finally the LIGR. The policy and economic implication is that the three levels of government in Nigeria need to strive harder to generate revenue independently to boost human capital capacity in the country. The undue dependence on allocation from the federation account should be curtailed to ensure that the maximum benefit of fiscal decentralization in the area of revenue and public service delivery is realized in all areas of human lives in the country.

Table 1. Model Summary Of Results

\begin{tabular}{lccccc}
\hline Model & $\mathrm{R}$ & $\mathrm{R}$ Square & Adjusted R Square & Std. Error of the Estimate & Durbin-Watson \\
\hline 1 & .912 & .832 & .786 & .012910664 & 1.824 \\
\hline a. Predictors: (Constant), LOGLIGR, LOGFIGR, LOGSIGR & & \\
b. Dependent Variable: HDI
\end{tabular}

Table 1 above gives the summary results of the model applied in this study. $\mathrm{R}$ is the correlation coefficient which measures the strength of linear relationship between two variables, therefore the closer the value to 1.0 or -1.0 , the stronger the association between the two variables (Gujarati \& Porter, 2009:20). The value of R which 
signifies the correlation between the dependent and the independent variables is $91.2 \%$. It shows the existence of a strong and positive relationship between the explanatory variables (FIGR, SIGR and LIGR) and the response variable (HDI).

$\mathrm{R}$ Square is the coefficient of determination which represents the square value of the $\mathrm{R}$, which is the correlation value. It shows the extent to which the independent variables account for the variation in the depend variable (Gujarati \& Porter, 2009:493). From table 1 above it can be observed that the $\mathrm{R}^{2}$ has the value of $83.2 \%$ which is very substantial. Therefore, it indicates the magnitude of the variation in HDI that independent variables can explain, while the remaining $12.8 \%$ is attributable to other factors that were not included in the model. Adjusted $\mathrm{R}^{2}$ shows the increase on $\mathrm{R}$ square caused by the total sum of independent variable.

Serial correlation also known as autocorrelation is the degree of a relationship between the error terms (Gujarati \& Porter, 2009: 412). Durbin-Watson test is used to test autocorrelation, and holds that values approaching 0 indicate positive autocorrelation, and values toward 4 indicate negative autocorrelation (Gujarati \& Porter, 2009: 434-435). However, values under 1 or more than 3 are a definite cause for concern (Durbin \& Watson, 1950, 1951; Field, 2009). The Durbin-Watson of this study is 1.824 which is approximately 2 indicating absence of serial correlation in the regression results and also satisfies the basic assumption of regression models that the error terms are independent (Australian Property Institute, 2015:487).

Table 2. ANOVA test results

\begin{tabular}{llccccc}
\hline Model & & Sum of Squares & Df & Mean Square & F & Sig. \\
\hline \multirow{2}{*}{1} & Regression & .009 & 3 & .003 & 18.169 & .000 \\
& Residual & .002 & 11 & .000 & & \\
& Total & .011 & 14 & & & \\
\hline
\end{tabular}

a. Dependent Variable: HDI

b. Predictors: (Constant), LOGLIGR, LOGFIGR, LOGSIGR

Source: Author's computation, 2019.

F-test is a test to establish the overall significance of the estimated regression analysis. It indicates the significance of the coefficients in the model for the number of independent variables used in the analysis (Gujarati \& Porter, 2009:240-242). Therefore, the F-statistics in this study is 18.169 with the p-value of $0.000<$ 0.05 level of significance. This result shows that the value of $\mathrm{F}$ is statistically significant and the model is suitable for the study. Thus, the implication is that the independent variables (FIGR, SIGR and LIGR) jointly influence HDI positively and significantly.

Table 3. Regression Correlations and Coefficients

\begin{tabular}{|c|c|c|c|c|c|c|}
\hline \multirow{2}{*}{\multicolumn{2}{|c|}{ Model }} & \multicolumn{2}{|c|}{ Unstandardized Coefficients } & \multirow{2}{*}{$\begin{array}{c}\text { Standardized } \\
\text { Coefficients }\end{array}$} & \multirow[t]{2}{*}{$\mathrm{t}$} & \multirow[t]{2}{*}{ Sig. } \\
\hline & & B & Std. Error & & & \\
\hline \multirow{4}{*}{1} & (Constant) & .223 & .058 & & 3.861 & .003 \\
\hline & LOGFIGR & .018 & .014 & .229 & 1.365 & .199 \\
\hline & LOGSIGR & .043 & .018 & .529 & 2.407 & .035 \\
\hline & LOGLIGR & .084 & .055 & .275 & 1.529 & .155 \\
\hline
\end{tabular}

Source: Author's computation, 2019.

The regression result of the model from table 3 above is a follows:

$\mathrm{HDI}=0.223+0.018 \mathrm{FIGR}+0.043$ SIGR +0.084 LIGR

The t-test on table 3 above is used to determine the acceptance or otherwise rejection of the null hypotheses earlier formulated.

\section{HYPOTHESIS I}

$\mathrm{Ho}_{1}$ : Federal government independent generated revenue does not have significant influence On Human capital development (HDI) in Nigeria.

The result on table 3 above indicates that FIGR t-test is 1.365 and the p-value is $0.199>0.05$ level of significance. This result shows that FIGR does not have significant positive impact on HDI, therefore, $\mathrm{Ho}_{1}$ is accepted and the alternative which suggests otherwise rejected. The result of this current study agrees with the findings of Shelleh (2017) but conflicts with the results of (Rashid \& Saqid, 2010; Jumad et al., 2013; Soejoto et al., 2015) who found evidence that fiscal decentralization influences human capital development positively and significantly. 


\section{HYPOTHESIS II}

$\mathrm{Ho}_{2}$ : State governments independent generated revenue does not significantly affect HDI.

SIGR t-test is 2.407 with the p-value of $0.035<0.05$ significance level. This result implies that SIGR have significant and positive impact on $\mathrm{HDI}$, therefore, $\mathrm{Ho}_{2}$ is rejected and the alternative established. The result of SIGR is in line with the findings of (Rashid \& Saqid, 2010; Jumad et al., 2013; Soejoto et al., 2015) but disagrees with Shelleh (2017) who found that revenue fiscal decentralization deteriorated institutional quality of 31 developing countries studied.

\section{HYPOTHESIS III}

$\mathrm{Ho}_{3}$ : Local government independent generated revenue does not significantly influence HDI.

The result on table 3 above shows that LIGR t-test is 1.529 and the p-value is $0.155>0.05$ level of significance. This result shows that LIGR does not have significant positive impact on $\mathrm{HDI}$, therefore, $\mathrm{Ho}_{3}$ is accepted and the alternative which suggests otherwise declined. The regression result for LIGR agrees with the findings of Shelleh (2017) but conflicts with the results of (Rashid \& Saqid, 2010; Jumad et al., 2013; Soejoto et al., 2015) who found evidence that fiscal decentralization influences human capital development positively and significantly.

\section{Conclusion and Recommendations}

\subsection{Conclusion}

The regression result of this study shows that federal government independent revenue effort is not sufficient to match with the spending responsibilities of the federal government on human capacity building outside the statutory allocation. In other words, it is evident that statutory allocation is heavily relied upon to shoulder federal government share of expenditure obligations on human capital development in the country. Besides negligence of human capital formation on the part of the federal government, this situation is also as a result of revenue leakages and corruption in the public sector preventing the flow of revenue into the federal government account. Although, the Treasury Single Account (TSA) was initiated in 2015 to curb this menace in the public sector administrative process, however, it is obvious that revenue leakages still occur.

\subsection{Recommendations}

Therefore, the study is recommending that all channels through which revenues are diverted for personal and selfish use of public officers should be checked and blocked. The federal government should consider human capital development as a major economic growth element to be encouraged.

There is a statistical evidence from the study that state governments' independent revenue influences human capital development in the country. This is a move in the right direction. However, the study recommends more revenue generation effort to cope with the pressing needs of human capital formation in the states, because there are states in Nigeria where majority of the youths are school drop outs coupled with high rate of illiteracy. Therefore, every state in the federation should work harder to develop the human beings for proper economic expansion in the country.

LIGR did not meet the a priori economic expectation, as a result, the study also recommends rigorous move to exploit all revenue opportunities in the local government areas and within the ambit of the law and constitution. If these resources are well harnessed, they will help to improve the local needs of people and encourage more skill acquisition among jobless youths and women.

\section{Acknowledgements}

This research is part of the Author's PhD research work supported by research grant from the Institute of Chartered Accountants Nigeria (ICAN). I sincerely appreciate Prof. John Uzoma Ihendinihu and Prof. Kabiru Isa Dandago for their mentorship and professional guidance.

\section{References}

Abiola, G. A., \& Ehigiamusoe, U. K. (2014). Analysis of internally generated revenue. And itsImplications on fiscal viability of states governments in Nigeria. Journal of Empirical Economics, 2(3), 216-228.

Australian Property Institute. (2015). The valuation of real estate. $2^{\text {nd }}$ Edition. Canberra, Australia: Appraisal Institute.

Bahl, R. W., \& Linn, J. (1992). Urban public finance in developing countries. Oxford University Press, New York. 
Bird, R. M. (1993). Threading the fiscal labyrinth: some issues in fiscal decentralization. National Tax Journal $\operatorname{XLVI}(2), 207-227$.

Bird, R. M., \& Wallich, C. (1993). Fiscal decentralization and intergovernmental relations in Transition economies: towards a systematic framework of Analysis. Country Economics Department working paper, WorldBank, Washington D.C.

Central Bank of Nigeria (2017). CBN Statistical Bulletin. Abuja, Nigeria.

Constitution of the Federal Republic of Nigeria (1999). Second Schedule. Part 1: Exclusive List. Part 11: Concurrent Legislative List. Part 111 Supplemental and Interpretation.

Dragusha, B., \& Osmani, E. (2012). The effects of fiscal decentralization in Albania. Iliria International Review, 2(1), 21-34. https://doi.org/10.21113/iir.v2i1.160

Durbin, J., \& Watson, G. S. (1950). Testing for Serial Correlation in Least Squares Regression, I. Biometrika, $37(3-4), 409-428$.

Durbin, J., \& Watson, G. S. (1951). Testing for Serial Correlation in Least Squares Regression, II. Biometrika, 38(1-2), 159-179. https://doi.org/10.1093/biomet/38.1-2.159

Field, A. P. (2009). Discovering statistics using SPSS: and sex and drugs and rock ' $n$ 'roll (3rd Edition). London. Sage.

Gogoi, A. (2017). A study on impact of fiscal decentralization on human capital development in India and an insight into the scenario of fiscal decentralization in Assam compared to India. International Journal of Interdisciplinary and Multidisciplinary Studies (IJIMS), 4(3), 524-535.

Gramlich, E. M. (1993). A policy-maker's guide to fiscal decentralization. National Tax Journal, XLVI(2), 229-235.

Gujarati, D. N., \& Porter, D. C. (2009). Basic Econometrics (5th Ed.). Boston: McGraw-Hill Irwin. ISBN 978-0-07-337577-9.

Harbison, F. H. (1973). Human resources as the Wealth of Nations. New York: Oxford University Press.

Iftikhar, A. (2016). Assessing the effects of fiscal decentralization on the Education Sector: A Cross-country Analysis. The Lahore Journal of Economics, 21(2), 53-96.

Jumadi, M. P., Ghozali, M., \& Khusaini, M. (2013). The impact of fiscal decentralization on local Economic development in East Java. IOSR Journal of Humanities and Social Sciences, 13(1), 01-07. https://doi.org/10.9790/0837-1310107

Lin, Y. (2018). Measuring well-being: A multidimensional index integrity subjective well-being And preferences. Journal of Human Development and Capabilities, 19(4), 456-476. https://doi.org/10.1080/19452829.2018.1474859

Oates, W. E. (1972). Fiscal federalism. New York: Harcourt Brace Jovanovich.

Oates, W. E. (1993). Fiscal decentralization and economic development. National Tax Journal, XLVI(2), 237-243.

Ocheni, S. I., \& Agba, M. S. (2018). Fiscal decentralization, public expenditure management and Human capital development in Nigeria. Academic Journal of Interdisciplinary Studies, 7(1), 153-162. https://doi.org/10.2478/ajis-2018-0016

Oti, P., \& Odey, F. I. (2017). Analysis of internally generated revenue and capital expenditure Utilization in Cross River State, Nigeria. International Journal of Development and Economic Sustainability, 6(1), 9-18.

Rashid, M., \& Sadiq, S. (2010). Impact of fiscal decentralization on human development: A case Study of Pakistan. The Pakistan Development Review, 49(4), 513-530.

Rauf et al., (2017). Fiscal decentralization and delivery of public services: Evidence from Education Sector in Pakistan. Studies in Business and Economics, 12(1), 174-184. https://doi.org/10.1515/sbe-2017-0013

Shelleh, Z. (2017). Impact of fiscal decentralization on institutional quality: Evidence from Developing Countries. M.A. Degree Thesis submitted to the Department of Economics Of the University of Ottawa, Ontario.

Soejoto, A., Subroto, W. T., \& Suyanto (2015). Fiscal decentralization policy in promoting Indonesia Human Development. International Journal of Economics and Financial Issues, 5(3), 763-771. 
Udoh, E., Afangideh, U., \& Udeaja, E. (2015). Fiscal decentralization, economic growth and Human resource development in Nigeria: Autoregressive Distributed Lag (ARDL) Approach. CBN Journal of Applied Statistics, 6(1), 69-93.

UNDP (2018). Human development index trends, 1990-2017. Human Development Report Office (HDRO), United Nations Development Programme. Retrieved from http://hdr.undp.org/ on January 10, 2019

Yasemin, I. C. (2016). Fiscal decentralization and inequality: The case of Spain. Regional Studies, Regional Science, 3(1), 295-302. https://doi.org/10.1080/21681376.2016.1183513

\section{Copyrights}

Copyright for this article is retained by the author(s), with first publication rights granted to the journal.

This is an open-access article distributed under the terms and conditions of the Creative Commons Attribution license (http://creativecommons.org/licenses/by/4.0/). 